This item was submitted to Loughborough's Research Repository by the author.

Items in Figshare are protected by copyright, with all rights reserved, unless otherwise indicated.

\title{
Policing and accountability: the working of Police Authorities
}

PLEASE CITE THE PUBLISHED VERSION

http://dx.doi.org/10.1080/10439463.2011.556734

PUBLISHER

(C) Taylor \& Francis

VERSION

AM (Accepted Manuscript)

LICENCE

CC BY-NC-ND 4.0

REPOSITORY RECORD

Millen, Floyd, and Mike Stephens. 2019. "Policing and Accountability: The Working of Police Authorities". figshare. https://hdl.handle.net/2134/15094. 
This item was submitted to Loughborough's Institutional Repository (https://dspace.lboro.ac.uk/) by the author and is made available under the following Creative Commons Licence conditions.

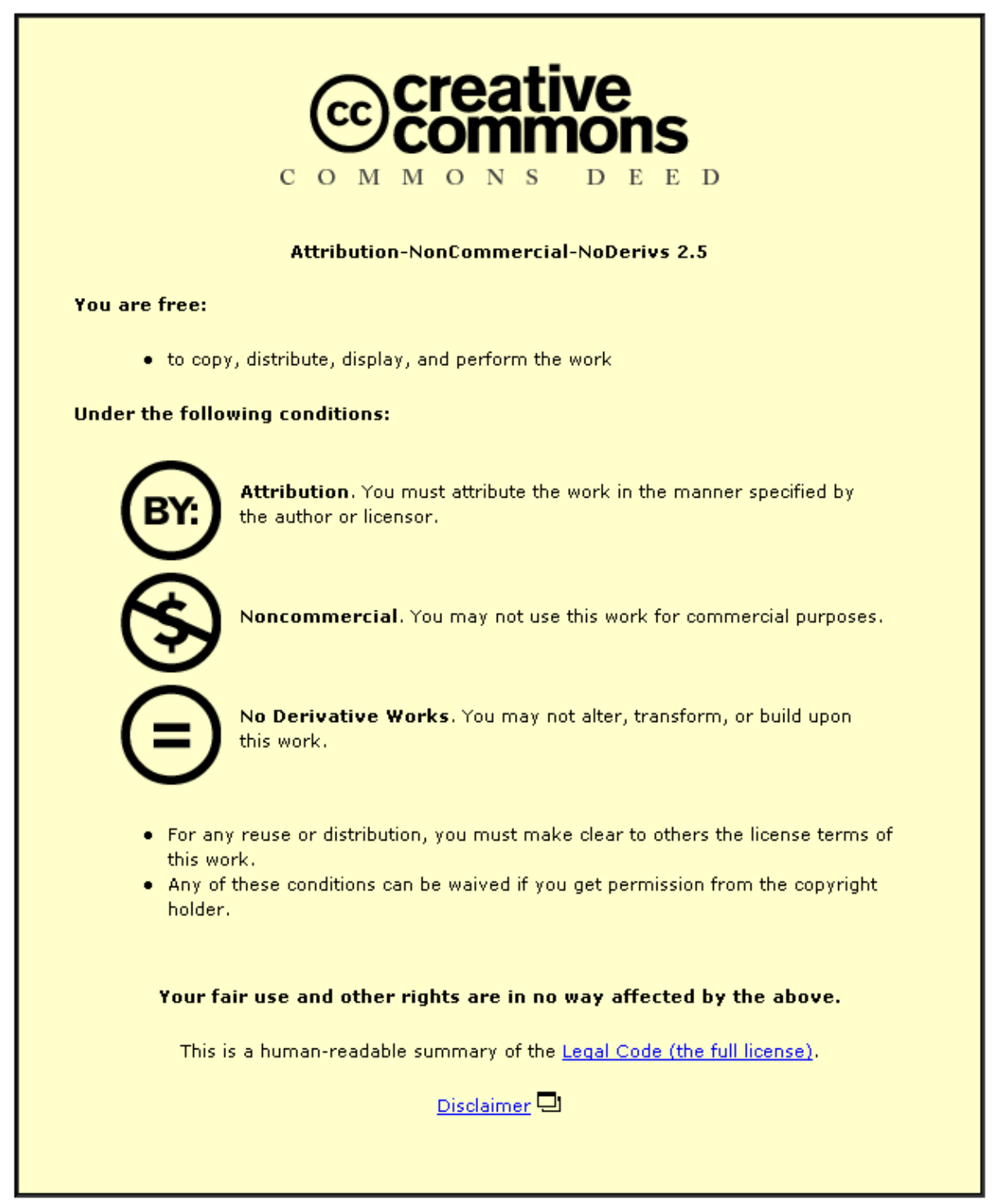

For the full text of this licence, please go to: http://creativecommons.org/licenses/by-nc-nd/2.5/ 


\title{
This is the version published in Policing and Society, Vol 21, No 3, September 2011, pp.265-283.
}

\section{Policing and Accountability: The Working of Police Authorities}

\author{
Dr. Floyd Millen and Dr Mike Stephens* \\ Department of Social Sciences \\ Loughborough University \\ Loughborough. LE11 3TU UK
}

\author{
*Contact for correspondence \\ m.r.stephens@lboro.ac.uk
}

\begin{abstract}
In recent times policing has attracted a good deal of controversy, such as the paramilitary tactics employed at demonstrations, the use of stop and search powers under the Terrorism Act 2000, and the manner in which police officers are deployed on day-today duties. This paper outlines the role and potential of police authorities to influence police policy and operations, and also highlights the need to seek greater citizen participation in holding the police to account. The major part of the paper draws on ground-breaking research on police authorities using questionnaire and in-depth interview data to outline just how it is that police authority members approach their duties.
\end{abstract}

Key words

Police authority, policing, accountability, participation.

\section{Introduction}

There was no grand design for policing in England and Wales; its development was never logical or systematic but was moulded by the needs and fears of society and then evolved over time as those needs and fears fluctuated and changed (Critchley, 1978). The transition from watch committees, the role of the justices and their powers to appoint chief officers along with the significant impact of the various acts of Parliament all set the scene for our 
current structure of policing and police authorities. Police authorities stand in a pivotal position to influence and improve upon our collective experience of policing, an experience in which the role of the citizen is crucial. Part of this paper discusses how the work of police authorities can and has impacted on participation by local citizens. As the bridge between local people and police forces, police authorities have a crucial role to play in building trust, gaining confidence and ensuring that the collective will is reflected in local policing.

The system of police accountability secures its legitimacy only if those who are able to bring the police to account fully understand their roles and responsibilities and the mechanisms through which an account can be brought (Audit Commission, 2003b; Docking, 2003; Myhill et al, 2003). What we have in police authorities and the tripartite system is an arrangement which ought to facilitate transparency and a higher degree of accountability: in reality however there appears to be insufficient access and knowledge of the process or the methods by which the citizen can influence policing and by policing can be understood. According to Jones et al (1994: 27), there is confusion and this confusion is intentional.

Police authorities are independent bodies and there is a police authority for each of the 43 police forces in England and Wales. The duty of the police authority is to set the strategic direction for the local police force whilst holding the chief constable to account on behalf of the local community for the policing service delivered. With the passing of the Police and Magistrates' Courts Act 1994 significant changes to both the composition and powers of police authorities came into force in England and Wales. The act made police authorities independent of local government and because combined, joint and single police authority structures were local government arrangements these structures became obsolete. The act also substantially reduced the size of police authorities and the numbers of elected councillors on them and independent members were introduced. As a result of the act, police authority membership consisted of 9 local councillors, 5 independent or appointed members and 3 magistrate members, totalling 17 members. Some police authorities had slightly more members; for example, the Metropolitan Police Authority had 23 members which enabled it to more adequately represent London's citizens. The role of police authorities was further redefined under The Police Act 1996 which paved the way for police authorities to take on an acute scrutiny role and a more direct involvement in the policing of their local areas. The Police Act 1996 gave police authorities specific additional responsibilities which included the requirement to publish local policing plans in consultation with local communities and other interest groups. The act also gave police authorities the responsibility of monitoring 
performance, collecting and publishing performance information, producing efficiency and Best Value performance plans, delivering best value, accounting for the constabulary's finances, managing the constabulary's resources, planning and deciding budgets, investigating complaints against senior police officers and monitoring overall complaints procedures through to appointing chief police officer.

The Crime and Disorder Act (1998) created Crime and Disorder Reduction Partnerships (CDRP) under which police forces and local authorities, in co-operation with police authorities and other agencies, were required to consult the public on a local audit of crime and disorder and a strategy for tackling them. The Crime and Disorder Act 1998 was a significant step forward in the drive towards increased accountability and representation because under it, and for the first time, local authorities became 'responsible authorities having a statutory responsibility to develop local crime and disorder strategies with the local police. The onus for crime prevention was now a joint responsibility between the police and local authorities (Crime and Disorder Act, 1998: section 5 (1-3)). The act required that all authorities - which included police authorities - should conduct audits to review the levels and patterns of crime and disorder in their area and to publish an analysis of that review. The purpose of the crime and disorder audit is to inform the partnership of crime and disorder in their area and identify the methods of developing and implementing plans. An important requirement that was set out in the act was that the audit involved local people and consequently looked to develop a wider perspective of how crime impacted on the community and how the community could have an impact on it. Police authorities were however not afforded the same status as local authorities or the police service: the passing of the Police Reform Act (2002) rectified this and police authorities were then given the same status as police forces and local authorities on Crime and Disorder Reduction Partnerships.

All police authorities are required to produce an annual policing plan which must consider the views of the local Community. The Crime and Disorder Act 1998 provided the remit for partnerships to be inclusive of agencies and individuals in their area. There was however a fear that because local authorities had more resources than police authorities that local authorities would expect to have a greater degree of influence over the local police leaving the police authority with very little influence when agreeing policing priorities or as both parties attempted to reach their targets of crime reduction. This situation could potentially arise because police authorities do not appear to impact (directly) on operational policing in the same way as the activities of the Crime Reduction Partnerships at the local and district 
level. At the end of their study of six police authorities Jones and Newburn (1997) concluded that although chief police officers still dominated policy and the planning process, the Police and Magistrates Courts Act 1994 gave police authorities potential strength that was yet to be applied in full. They concluded that if police authorities worked in a seamless way with the chief of police then there would be very little room for the authority to be undermined or sidelined at the local level. We can therefore see that police authorities are potentially more powerful than may be initially apparent. However, the degree of influence and power that they can exert is very much dependent on their ability to work in a unified way at the local level with local authorities, fire and rescue authorities, local health boards (in Wales), Primary Care Trusts (PCT) as outlined in The Crime and Disorder Act 1998.

\section{Accountability and Citizen Participation}

According to the Policy Studies Institute (1997), despite initial criticisms that the Police and Magistrate Court Act 1994 represented an attack on democratic accountability, there was evidence that local police authorities were actually re-invigorated as a result of it. The Policy Studies Institute (1997) also found that the most criticised aspects of the act - the reduction in police authority size and the introduction of appointed independent members - made police authorities more active and influential and rather than increasing central control, many forces and police authorities had used local policing plans to introduce a range of local police objectives, including crime prevention and quality of life issues such as traffic calming measures and road safety. Notwithstanding this, however, police authorities were effectively less democratic and their local plans had to take account of national issues which at times were at odds with local concerns. Moreover, the police authority is also dependent on the police service through the commissioner or the chief constable to relay information to them via reports presented to the police authority. Baldwin and Kinsey (1982) and Marshall (1978) highlight section 12.3 of the Police Act 1964 because it provides chief constables with an exit clause if they think that by submitting a report it would result in the disclosure of sensitive information that could jeopardize or influence operational policing. Chief constables are permitted to refer such requests for a report to the Home Secretary who has the final decision on what if anything is presented. This places the police authority at the mercy of the police service (Day \& Klein, 1987). It is quite possible that the Home Office and the chief constable could agree to support each other in decisions to the exclusion of the police authority (Lustgarten, 1986; Baldwin and Kinsey, 1982; Marshall, 1978). Lustgarten (1986) sees this level of dependency as unsatisfactory and for Jones et. al. (1994: 27) the 'tripartite system is 
ambiguous, not at all transparent and [this confused arrangement is in their opinion] intentionally constructed'. The reality is that many of the powers conferred on the police authority are only exercisable through the authority of the Home Secretary. Even though there have been a number of acts of Parliament reorganising our police service and the role of the police authority within the tripartite structure, very little has actually changed - since the Metropolitan Police Act 1839 - to alter the spread of power between the members of the tripartite system. The potential for further confusion or tension is heightened by the fact that police authorities - in their current form - are a newly introduced partner juxtaposed between two long established institutions - the Home Office and the police service - that have developed strong working ties and systems of operation over many years. Finally, police authorities are further challenged by their primary duty to secure the maintenance of an 'adequate and efficient' force for their area (The Police 1964 Act, section 4.1; APA, 2005; Boateng, 1985: 238) which could be seen as in conflict with their scrutiny role.

\section{Representation Trust and Accountability}

The policing issues which concern local people can be highly emotive and there are a multitude of voices vying to be heard; questions are inevitably asked as to why there are such low levels of participation from the public. It is therefore questionable how effective police authorities are in representing the diverse views of those they are serving. The level of participation and the frequency of consultation are in themselves an insufficient barometer of accountability. The Audit Commission (2003a; 2003b) conducted research on accountability, public trust and confidence in public services. The Commission found that people trusted individuals much more than organisations because the notion of trust was based on relationship, familiarity and experience. The report found that public trust in the accountability structures of public organisations was driven by various factors including useful and credible information, the existence of external watchdogs, personal contact, and unsurprisingly - whether they were seen to be honest and trustworthy (Audit Commission, 2003a). The Audit Commission rated the police as the worst of three services in providing information although the police was the institution that was seen as most likely to be controlled by an independent watchdog. The Audit Commission (2003a) found that generally, public trust in local authorities was low and the reason that it was much lower in the police was primarily because the public did not think that the police would listen to their views and also that public awareness of the regulators was low. 
Having being charged with certain responsibilities, duties and functions police authorities have an obligation to be directly accountable to the communities within their geographic boundaries as much as they are accountable to the Home Secretary and chief constables within the tripartite structure. In the first instance accountability to the local community is of paramount importance because it is here that the effects of policing or lack of it will be felt. For particular groups, the distinction between operational and non-operational policing is irrelevant because their primary experience is confrontational and adversarial. The preoccupation with the tripartite structure implicitly denies the place and importance of the citizen. It is important for the effective functioning of the police that we begin to acknowledge that the tripartite system is in fact a quartet of Home Secretary, chief constables/commissioners, police authorities and the citizen. The system ought to work on behalf of the citizen not the citizen on behalf of it. Scarman $(1986,4.60)$ noted; '... [the police] enforce the law on behalf of the community; indeed they cannot effectively enforce it without the support of the community'.

Public knowledge of the existence of police authorities is crucial if the authority is to be effective and have the credibility required to undertake its role. Both Myhill et al (2003) and Docking (2003) in their respective research found little public awareness about police authorities and their roles. The call for greater public accountability dictates that the institutional mechanisms set up to bring about that accountability have: a) sufficient expertise, b) that there is knowledge of the institution its role and mechanisms, c) that it is resistant to being unduly influenced and d) that it has the resource capability to deliver.

In most cases the above requirements have indeed been met. For example, police authorities arguably have the basic structural framework, resources and relevant powers to enable them to perform their functions. They have responsibility for setting the police budget; they have the additional resources and expertise of its members who are magistrates, independent and local authority members. There is also the appointment of civil staff whose role it is to support the appointed members in their work for the authority. Both police authority members and the civil staff work closely with the local police force to produce local policing plans and the chief constable or commissioner reports on a monthly basis to the authority on the activities of the force. 
In addition to the above, there have been calls for the strengthening of police authorities which have, according to Jones and Newburn (1997), sprung from concerns that the division of responsibility between the Home Office, police authorities and chief constables is deliberately confusing and thereby obscures the decision making process; and secondly, that there is a shift of power away from police authorities to the Home Office and chief constables (Reiner, 1992). The compound effect of this according to Jones et al (1994) is that there are very few checks and balances in the system not only because police authorities and its members have insufficient knowledge but also they lack the formal powers they need to exert real influence.

Moreover, Jones and Newburn (1997) found that police authorities were increasingly preoccupied and focussed on managerial and organisational issues rather than the strategic policy issues governing local policing. The researchers concluded that there was a move towards a calculative and contractual accountability as opposed to accountability based on explanation and cooperation. There is, therefore, a growing feeling that police authorities have little real control or power and are unable to bring chief constables and their police services to account (Reiner, 1991; Loveday and Reid, 2005; Jones and Newburn, 1997).

\section{Methodology}

There are approximately 760 police authority members in the 43 police authorities in England and Wales. In November and December 2007 questionnaire surveys were sent to all police authorities and initially 81 were returned. In January 2008 a further 200 questionnaires were sent out and a further 27 completed questionnaires were received, totalling 108 (14.2\%). Some police authorities have generic email addresses where all correspondence is filtered to the police authority member by Member Services. However, where direct contact details were available the questionnaire was sent directly to individual police authority members. Some police authorities such as Hertfordshire Police Authority have a designated member to respond on behalf of the police authority. While the total number of respondents that returned completed questionnaires was 108, the total number of responses for each question varies considerably as some respondents provided multiple answers to some questions.

New empirical ground has been covered by this research as the literature reveals no similar survey which has focused on police authority members. In addition, 24 semi-structured, indepth interviews were conducted with specific individuals who are significant gatekeepers 
between the community, the police service and the police authority. Interviewees included 17 police authority members, a former Home Secretary, the Chairman of the Association of Police Authorities, the Executive Director of the Association of Police Authorities, the Policy Officer of the Association of Police Authorities, the Clerk to the Metropolitan Police Authority, a former chief constable and a grade 5 civil servant. All interviewees in this research were advised that if they wished to remain anonymous or if they wanted to speak off the record, they were free to do so. Anonymous interviews enabled the researchers to draw out important issues to the phenomenon being studied by allowing participants to describe in detail their experiences.

Between 1964 and 1994 there has been a small body of work on police authorities (Jones \& Newburn, 1997; Brogden, 1977; Reiner, 1991). In the last decade, however, this paper sets out the most recent academic work on police authorities and is the only academic work to look at the role of police authorities in the context of citizenship and accountability. The current paper explores the following:

a) The relevancy of police authorities, their potential and their actual impact,

b) The role of police authorities in relation to the citizen, the police service and accountability.

c) The views of police authority members on how they perceive their role and the role of the police authority.

\section{Findings}

This research has shown that 68 out of the 126 (54\%) responses by police authority members to the question of responsibility accepted that the police authority was ultimately responsible for policing in their area and as far as responsibility was concerned they ranked the police service and the Home Office in second (29) and third (21) place respectively (Fig.1). 
Figure.1 Who is ultimately responsible for policing?

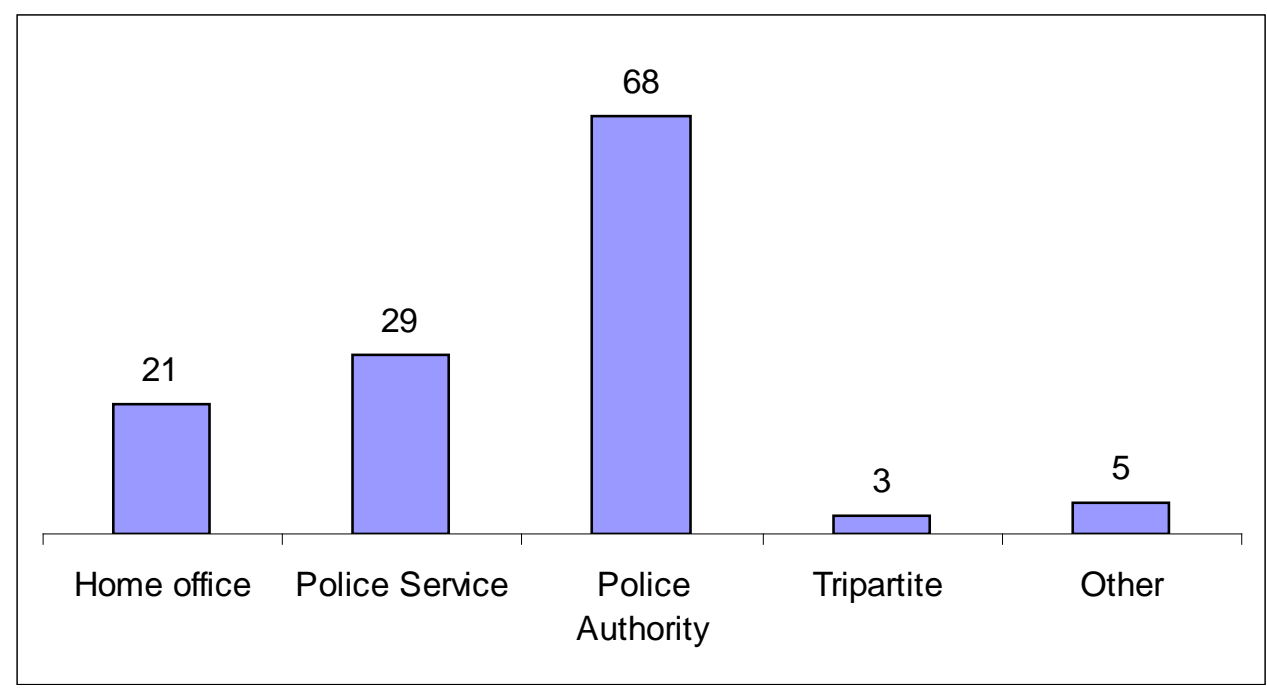

The question of 'who is ultimately responsible for policing' was - in effect - a statement of duty rather than legal responsibility. Whilst members accepted that responsibility for policing ultimately lay with them as police authority members, further analysis of the responses reveals a clear disconnection between the perceived balance of responsibility (Fig.1), the right to make final decisions in disputes (Fig.2), and the perceived possession of power (Fig.3). Responses to Figure.3 show that whilst members felt the police authority had the least power within the tripartite system, they perceived that it had the most responsibility. This viewpoint was further reinforced when members responded to the question: 'who they thought had the final decision in disputes?'” (Fig.2). The overwhelming view was that the Home Secretary clearly had the final decision. In-depth interviews with police authority members shed further interesting light on this issue. One independent member of Llandudno Police Authority forcibly emphasised during the interview that wherever the power and final decision lay, it was most definitely not with the police authority. He explained:

'... I sometimes ask in a meeting - and publicly - if we vote against this [action, policy or direction] what will happen? and the answer is that it will go ahead anyway!'

Figure.2 In disputes who has the final decision? 


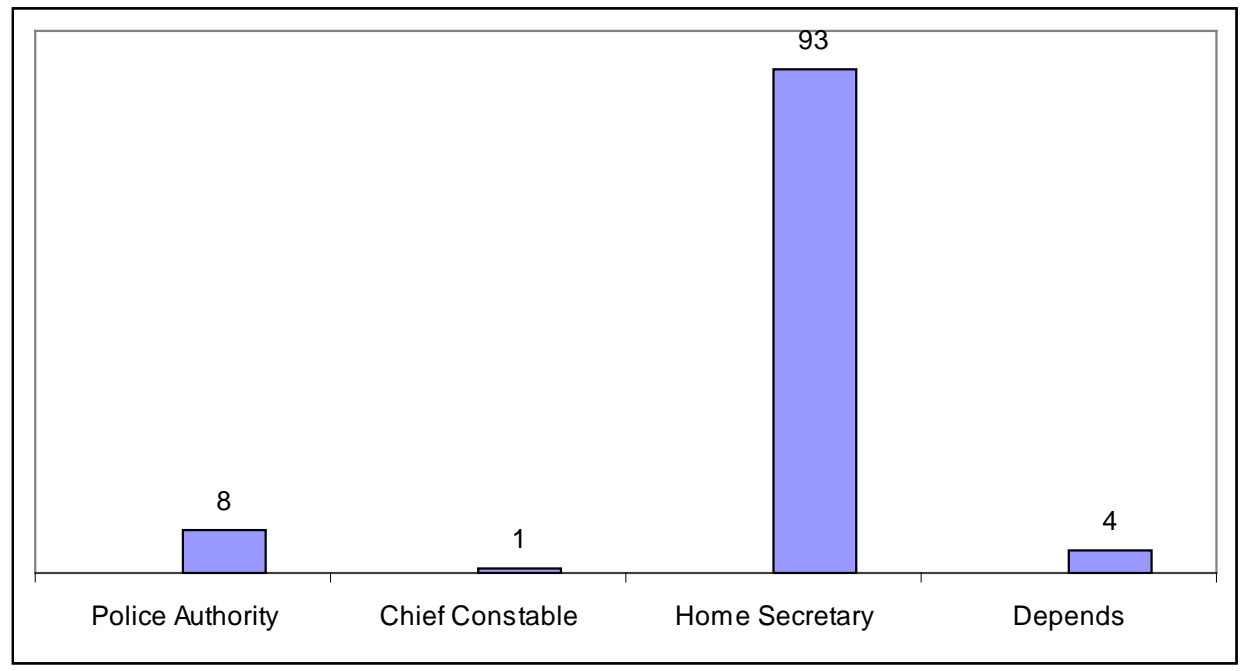

Fig.2 shows that the vast majority of the sample believe that the Home Secretary has the final decision in disputes. Fig.3 also provides contemporary support to the position expounded by Reiner (1991) that the Home Secretary and chief constable hold the balance of power. Reiner (1991) observed that during the dispute over the purchase of plastic bullets and CS gas in Northumbria, the chief constable got his way primarily because the police authority could only exercise influence as long as the chief constable and the Home Office permitted the police authority to do so. Even though the police authority appealed against the original decision, the Court of Appeal rejected their appeal on the grounds that the Home Secretary had powers under the Royal Prerogative to do what he felt was necessary in order to keep the Queen's Peace (Reiner, 1992: 240). According to Reiner (2000: 189) and Brogden (1977) in cases of real conflict between a chief constable and his police authority not only would the chief constable always prevail but the police authority would defer to the expertise of the chief.

Figure.3 Where does the balance of power reside? 


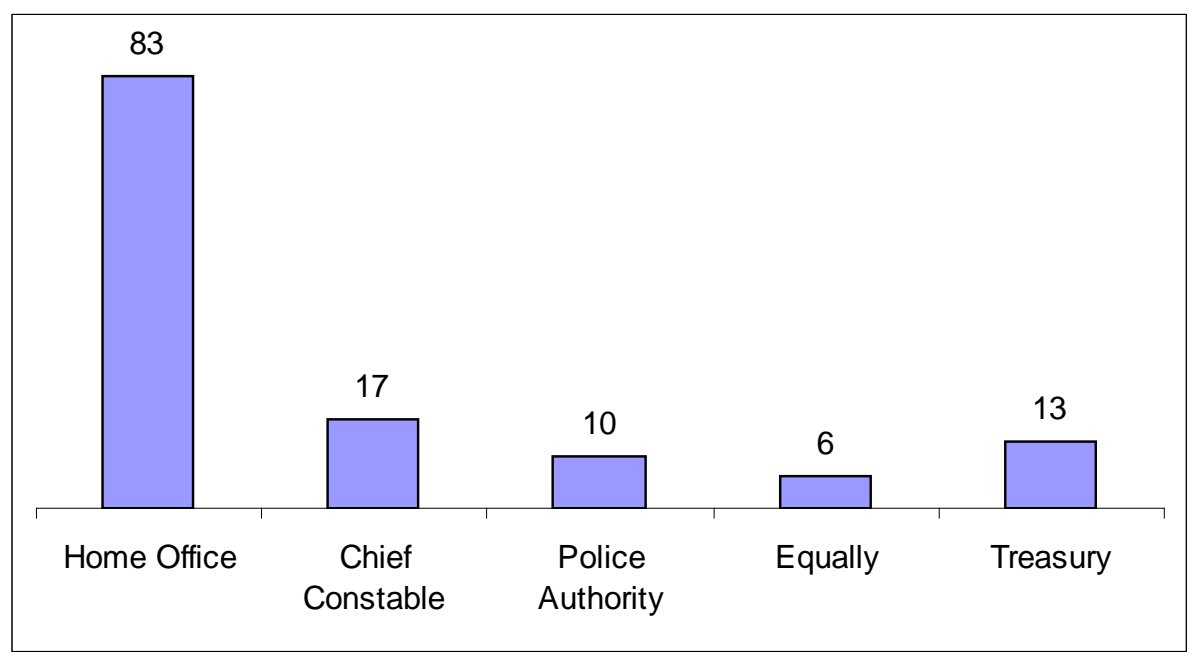

In relation to the tripartite system, the questionnaire asked where police authority members thought the balance of power rested. The results are interesting because even though Her Majesty's Treasury (HMT) sits outside the formal tripartite system arrangement, thirteen police authority members felt that HMT wielded sufficient power and in fact had more power than the police authority and came close to the power and influence of the chief constable (Fig.3). During an in-depth interview, a councillor member of Cumbria Police Authority explained that those members who saw the Treasury as an important power base did not quite understand how public finances worked. He explained that the balance of power was - in his opinion - tilted in favour of the Home Office. Interestingly, he also cited that the Association of Chief Police Officers (ACPO) potentially wielded more power than the police authority or the police authority's representative organisation the Association of Police Authorities (APA).

Closer analysis of Fig.3 suggests that there is a lack of understanding by a large number of police authority members of their budgetary powers to effect change. Fig. 1 reflects that police authority members accept their responsibility: however, the collective responses between figures 1,2 , and 3 suggest that much more needs to be done to train and re-skill members. This concurs with the views of a clerk of a police authority who explained during interview that because the police authority receives the funds and is responsible for the budget, it is crucially important for members to understand fully the budget and the impact it has on policing.

The former Home Secretary Rt Hon Charles Clarke MP saw the balance of power as primarily residing with the chief constable and saw that the onus was on the police authority to find a way to work with the chief of police whom he saw as controlling operational 
policing. Reiner (1991) noted that over time there had been a detrimental shift of power away from police authorities to chief constables. An independent member of Llandudno Police Authority felt that the relationship was '...more about influence rather than power' which suggested that far from the 'self limiting' description of Jones et al (1994: 62), the police authority was able to exercise its influence through a more complex process of negotiation rather than through the overt display of power.

According to a councillor member of Sussex Police Authority: 'the Home Office consistently tries to tip the balance in its own favour but the police authority's role is to remind them [the Home Office] that the local view is of crucial importance.'

Figure.4 Within the tripartite system is the police authority proactive or reactive?

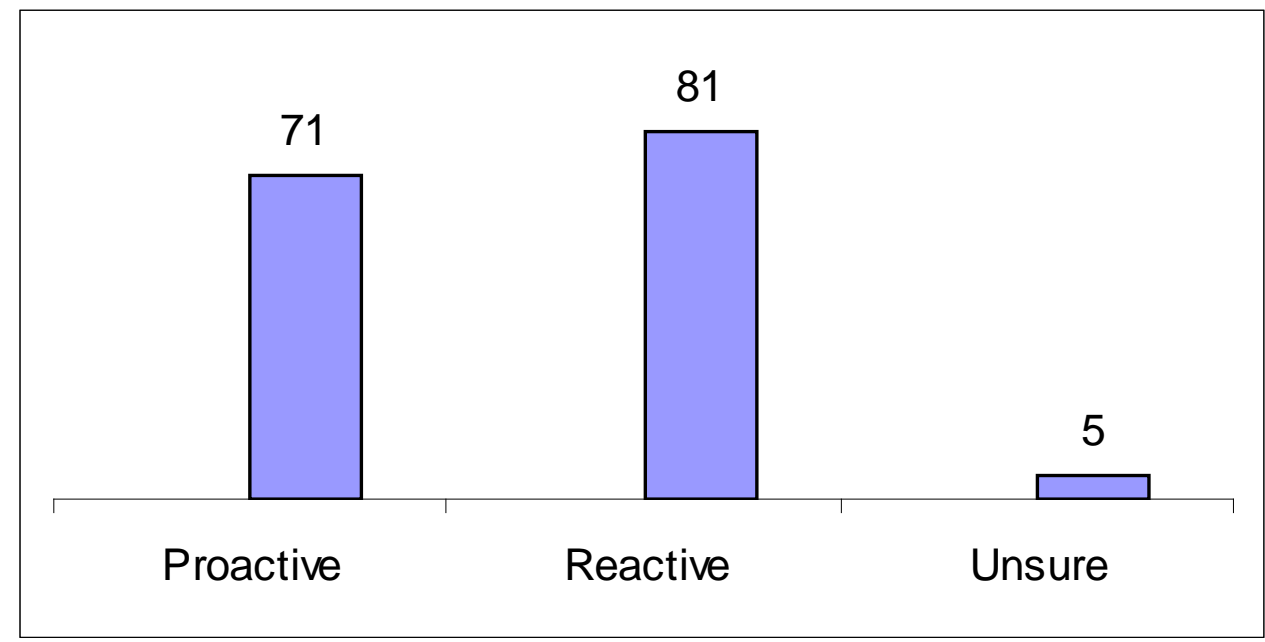

On the question of whether members thought their police authority was proactive or reactive, Fig. 4 shows that over 81 of the 157 responses indicated their belief that the police authority was more reactive than proactive. Despite this, an independent member of the Metropolitan Police Authority saw the police authority as primarily a proactive body; setting the agenda, the tone and actively pursuing issues. He argued that in order to effectively fulfill its role police authorities had to be proactive. A councillor member of Sussex Police Authority explained that as a police authority Sussex tried to be proactive but ' .... at the end of the day we are lay people and are not involved 24 hours a day, seven days a week'. Other interviewees also echoed this and saw their police authorities as more reactive than proactive. Typical of this view was the following: '...there is a degree of inevitability because just in 
terms of energy and resources there is a squad of people [police and civil staff] paid and working fulltime... this is where the power lies'.

Figure.5 Who do members represent?

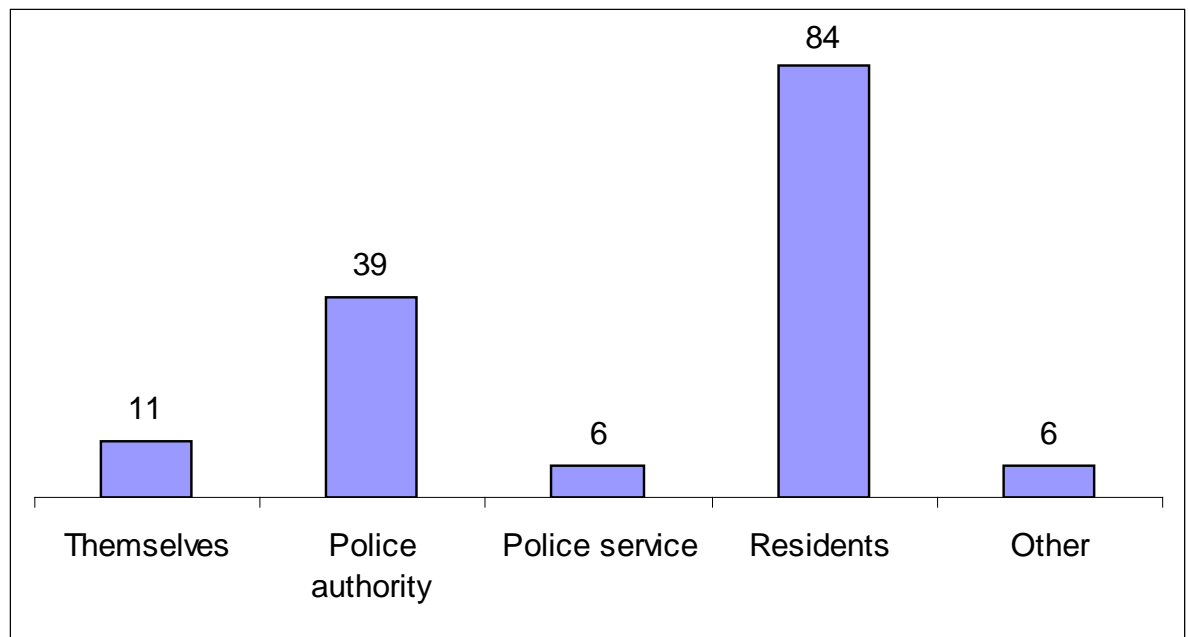

Eighty four members (Fig.5) saw themselves as primarily representing the residents in their local areas while 39 saw that they had a responsibility to represent the police authority. What is clear is that in order for police authorities to be effective there needs to be a balance between the responsibilities of members to represent and consult with local people - which is a responsibility given to police authorities under the Police and Criminal Evidence Act (1984), the Police and Magistrates Courts Act (1994) and the Crime and Disorder Act (1998) - and the responsibility of the police authority under the provision of the Police Act (1964) (section 4.1) 'to secure the maintenance of an adequate and efficient police force for the area'. The job description for police authority members clearly reflects this aspiration stating that members are appointed to fulfill a dual role; ' ... to represent the views of the police authority within local communities and the views of local communities to the authority' (Leicestershire Police Authority, 2007).

Figure.6 Are members doing enough to represent those identified in Fig.5? 


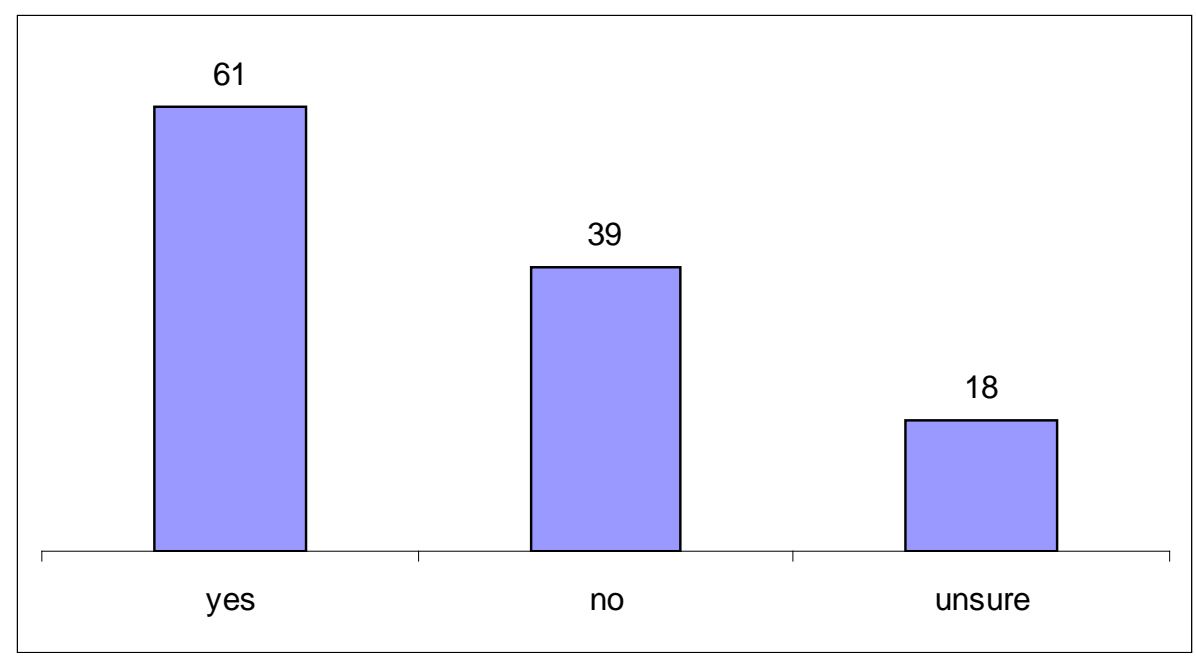

Figure.7 Is the police authority doing enough to represent its constituents?

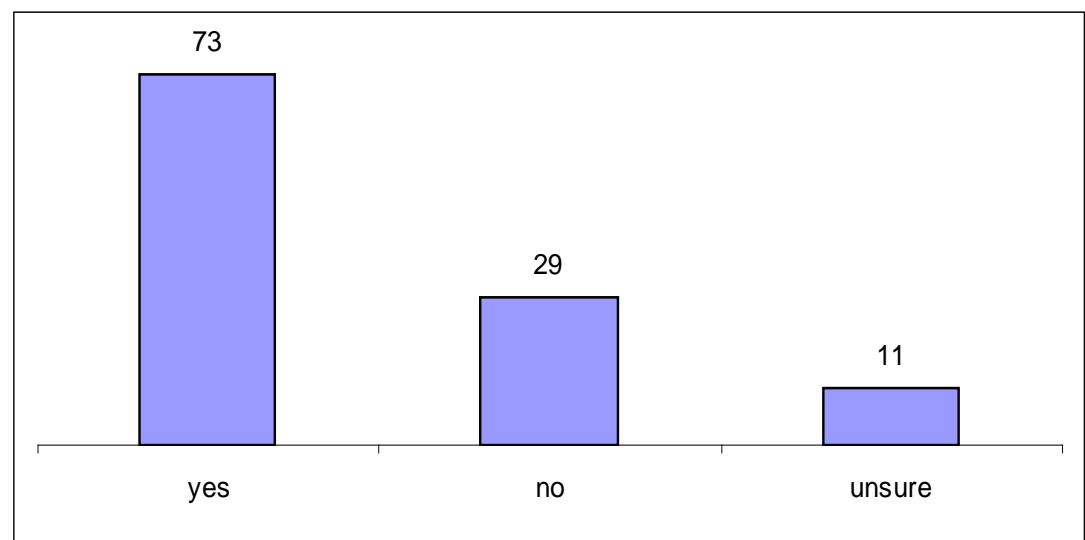

On the question of whether police authorities were doing enough to represent residents, the police service and the wider community, 73 responses (Fig.7) indicated that members thought their police authority was doing enough to represent those within its remit and area of responsibility. Even though 61 responses (Fig.6) indicated that members felt that they and other members like themselves were doing enough to represent those they had identified in Fig.5, 39 members (Fig.6) indicated that as members they were not doing enough whilst 18 were unsure about whether they were doing enough to represent effectively.

At the heart of the question of whether police authority members are doing enough to represent the interests of those who depend on them is the question of whether members 
know how to bring the chief constable/commisioner to account and more specifically what questions to ask. According to Day \& Klein (1987) police authority members lack sufficient knowledge and understanding resulting in them being unable to ask the right questions. This situation is made worse because members are unaware of their legal powers which invariably render them relatively powerless and unable to exert real influence or control. One Metropolitan Police Authority member explained that in her experience,

'... in order to know what questions to ask you read a lot! The commissioner is at our behest and we know what to ask by doing our own research in the same way journalists do. If we attend meetings and expect things to be handed to us we are not doing our job’.

A councillor member of Sussex Police Authority and a councillor member of North Yorkshire Police Authority both argued that local knowledge and experience were vital if members were to be effective and to know what to ask.

An independent member of Llandudno Police Authority explained that members are appointed not as experts but because they have been 'round the block' and the variety of experience that comes to the authority particularly from those with public sector experience is considerable. This response implies that members are pragmatic and aware that their scope of effectively holding the police to account is potentially restricted by the resource and time implications that go along with the terms of their appointment.

Figure.8 How effective are Community Police Consultative Groups (CPCG)? 


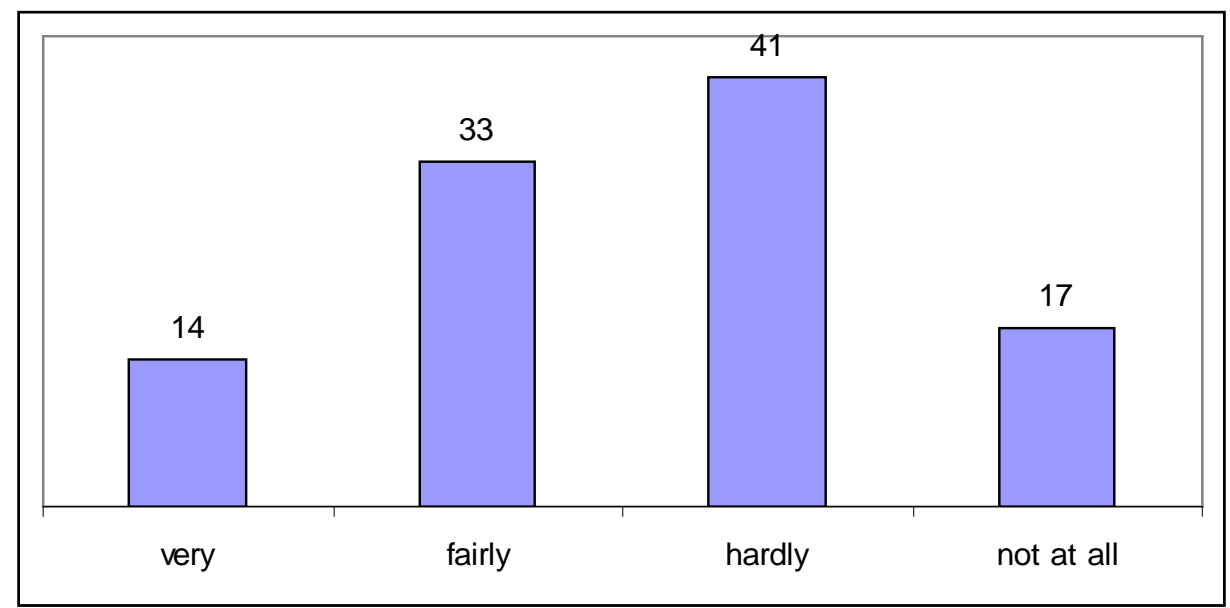

Figure.9 Do they attract a representative audience?

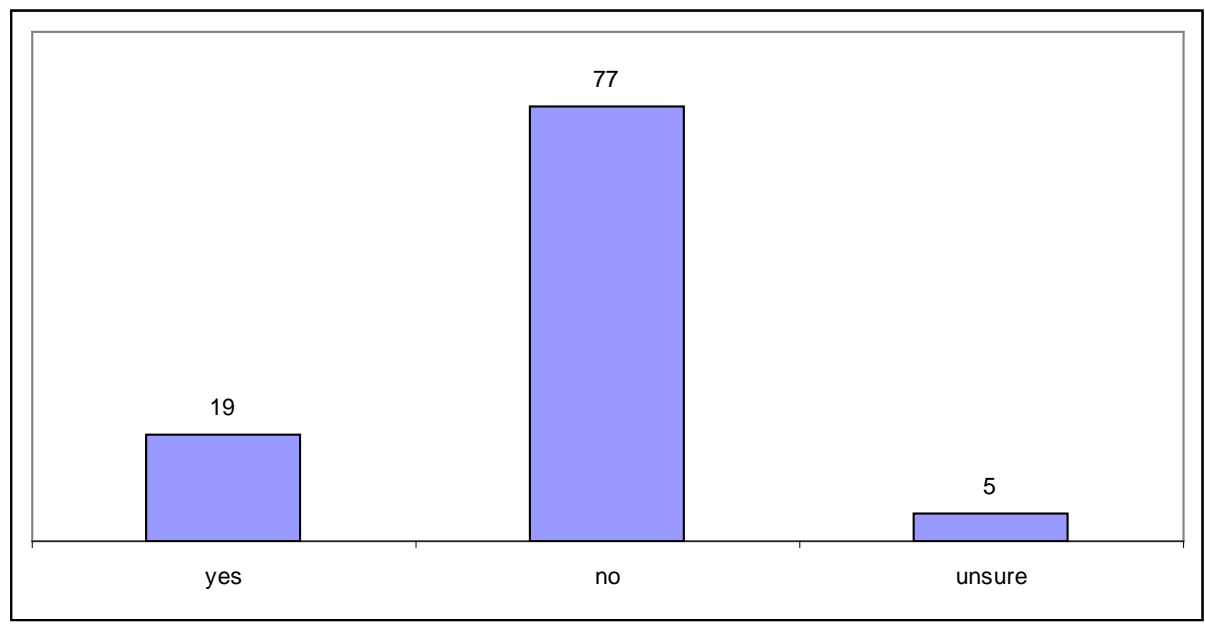

Given the importance of consultation, 47 members saw Community Police Consultative Groups (CPCG) as very or fairly effective and 58 thought CPCGs were hardly or not at all effective (Fig.8). The overwhelming view amongst those police authority members who responded to this particular question was that where the old consultative arrangements were still in place 77 (76\%) out of 101 responses indicated that the forums did not attract a sufficiently representative audience (Fig.9). One Metropolitan Police Authority member colourfully described CPCG's '...some of them are really shit! Some of them are really good...'.

Figure.10 Can accountability be strengthened by electing police authority chairs and members? 


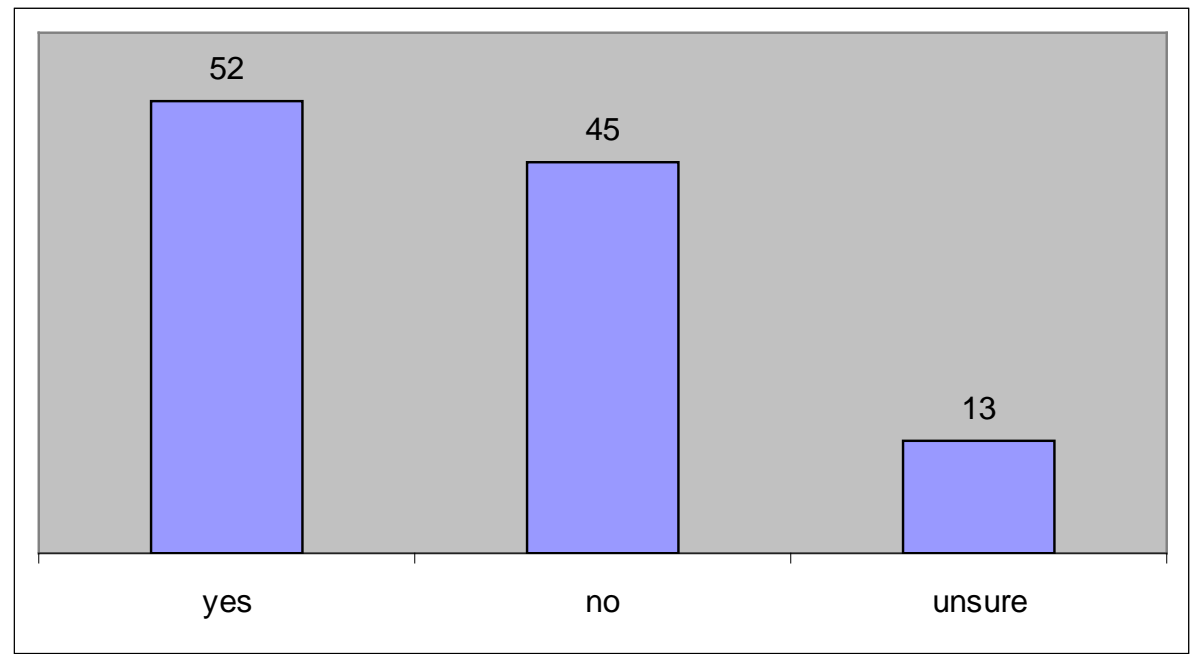

According to Howard (2005), and Loveday and Reid (2003) accountability could be enhanced and supported by the direct election of officials including police authority members and chief constables/commissioners. The results from this survey have shown that whilst 52 police authority members believed that accountability could and would be strengthened by electing police authority chairs and members (Fig.10), there was no evidence to support the assertion that the process of elections would make the work of the police authority more accountable or indeed more effective. A councillor member of Cumbria Police Authority explained that 'electing members would be stupid and electing chief constables would be equally stupid!' An independent member of the Metropolitan Police Authority also supported this position and explained that elections would not make the police authority more efficient and that she was certain that the elected route would simply maintain the status quo by electing white male professionals.

A former chair of the Metropolitan Police Authority agreed with the prevailing view of interviewees in this research that electing chief officers made very little sense; '... the electoral process would not [in my opinion] give you professional competence, but different skills.' He did however echo a similar view to that articulated by Loveday and Reid (2003: 59) that 'electing the chair of police authorities had some virtue because it would give clear political accountability'. However, what was more important to this interviewee was the diversity brought to the police authority by independent and magistrate members who may not otherwise have gained a place on the police authority through an elective process.

Figure.11 Would electing members be more democratic than appointments? 


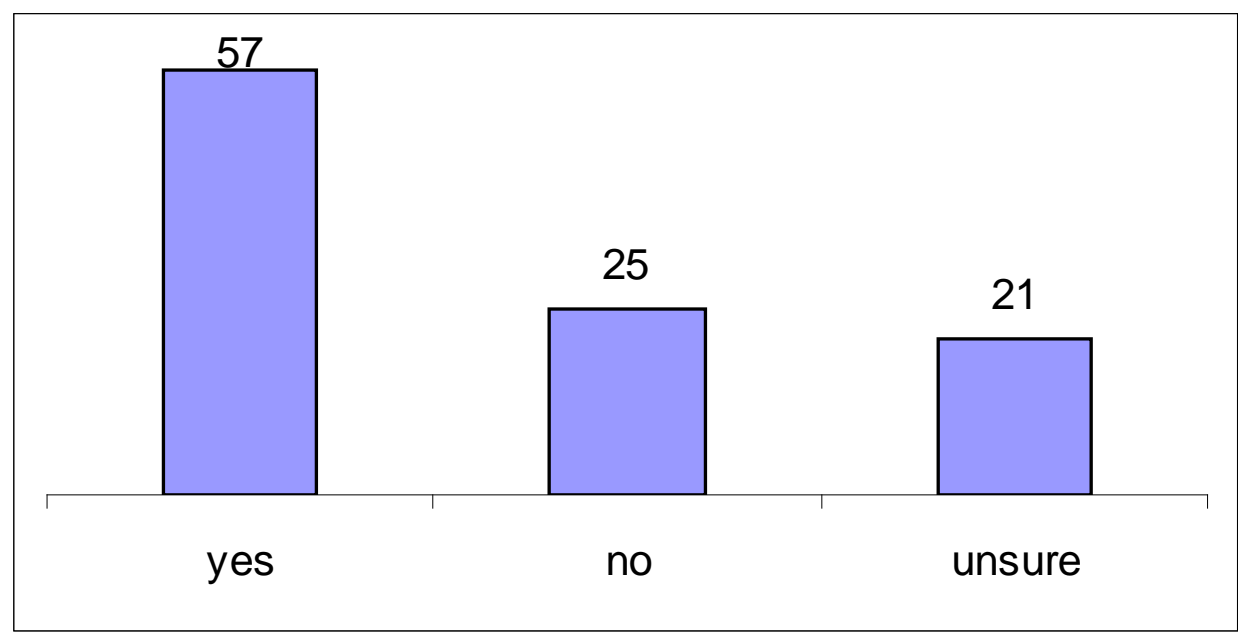

Even though 57 respondents thought that electing police authority members would be more democratic than a recruitment process (Fig.11), the reality is that the merits of appointing through a recruitment process cannot be assessed against that of an electoral one because both processes are attempting to select people using different criteria. The overwhelming majority of interviewees accepted that whilst an elected system would be more democratic, selecting members through such a process was far less desirable. One Metropolitan Police Authority member asked: 'why would you elect a commissioner of police when you do not elect the head of the fire service or the head of any other similar service?' Loveday and Reid (2003) were also of the opinion that if all members were elected, the lack of independent nonpolitically partisan members on police authorities would not be good for local communities.

Figure.12 Would elected chief constables improve accountability and give the local community a greater say? 


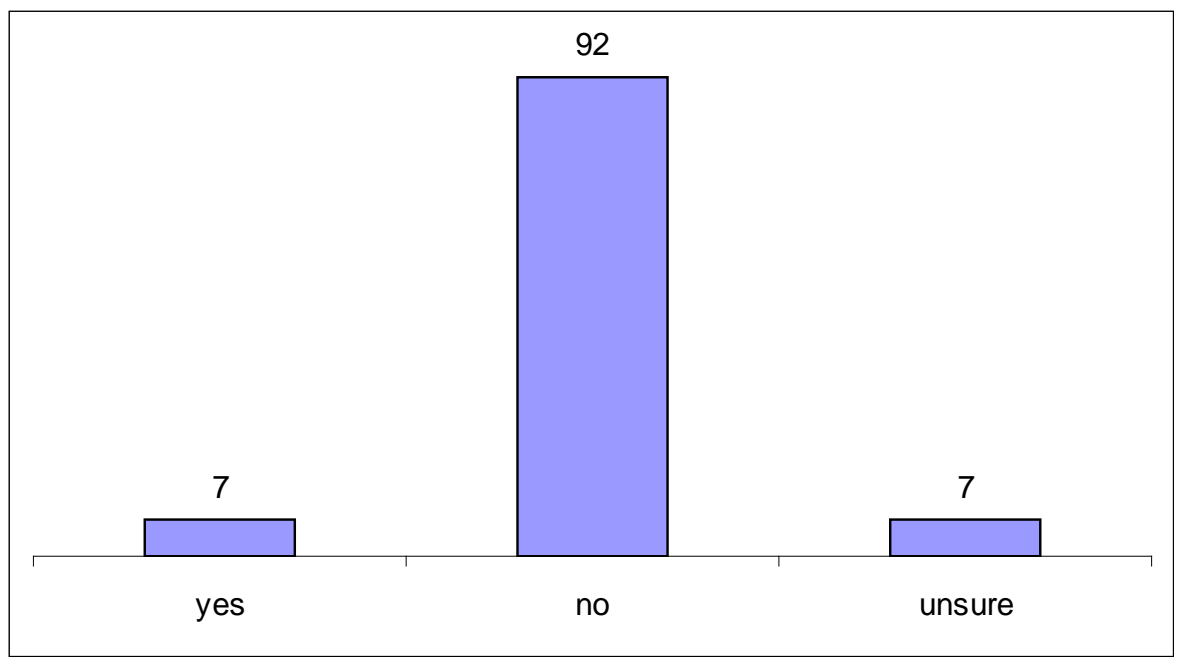

On the prospect of electing chief constables or commissioners, 92 members (Fig.12) did not believe that elections would improve accountability or increase the voice of the local community and there was consensus that trained professional police were best placed to fill these roles as opposed to professional politicians.

‘... Policing is a professional responsibility and any suggestion of political influence in the appointment of a senior officer would be a mistake' (former Home Secretary Rt Hon Charles Clarke MP).

A councillor member of Sussex Police Authority added that '.. an elected chief is far too American for my liking ....'. Thirty respondents believed that directly electing chief constables/commissioner would result in a reduction in accountability because this accountability would be to the electorate and not accountability in terms of stewardship (Pyper, 1996), rectification (Mulgan, 2003: 30) or 'the ability to impose a cost' (Keohane, 2002: 479). Forty seven respondents believed elected chief constables would have no impact whatsoever and only 13 respondents thought that there would be an increase in accountability.

Figure.13 Do you think the citizen knows about police authorities? 


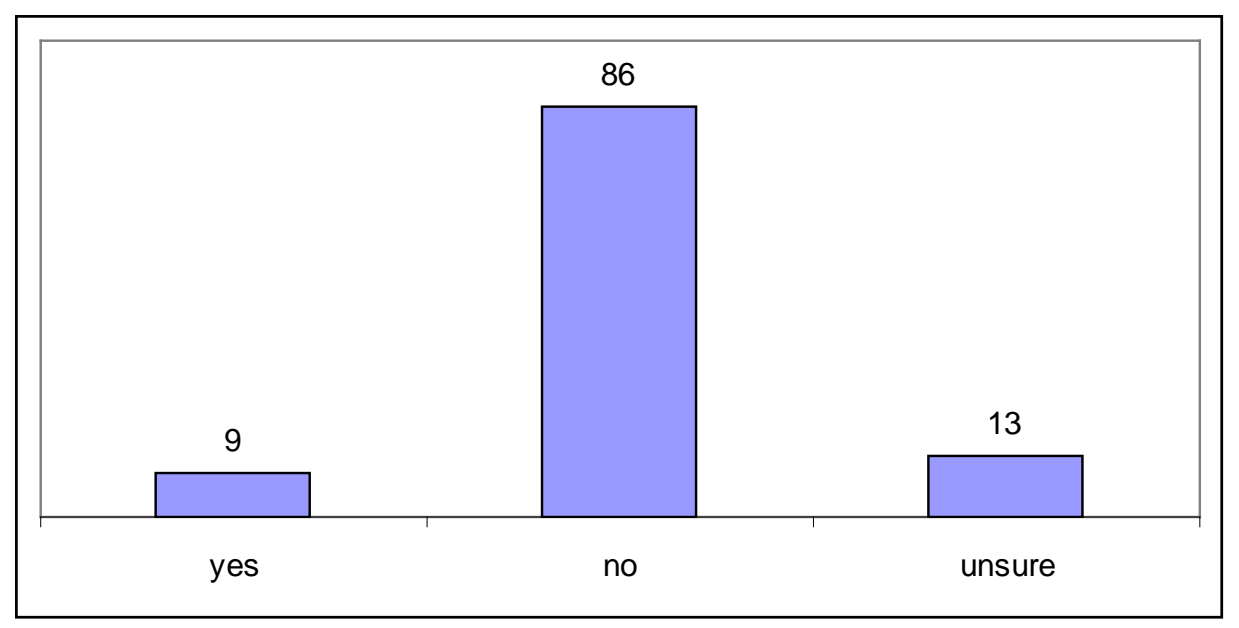

Even though 84 police authority members saw their primary role as representing local people (Fig.5) 86 members felt that the citizen did not know about the police authority (Fig.13) and 13 members were unsure whether or not the citizen knew about them.

Figure.14 Do you think citizens are aware of the distinction between the police service and the police authority

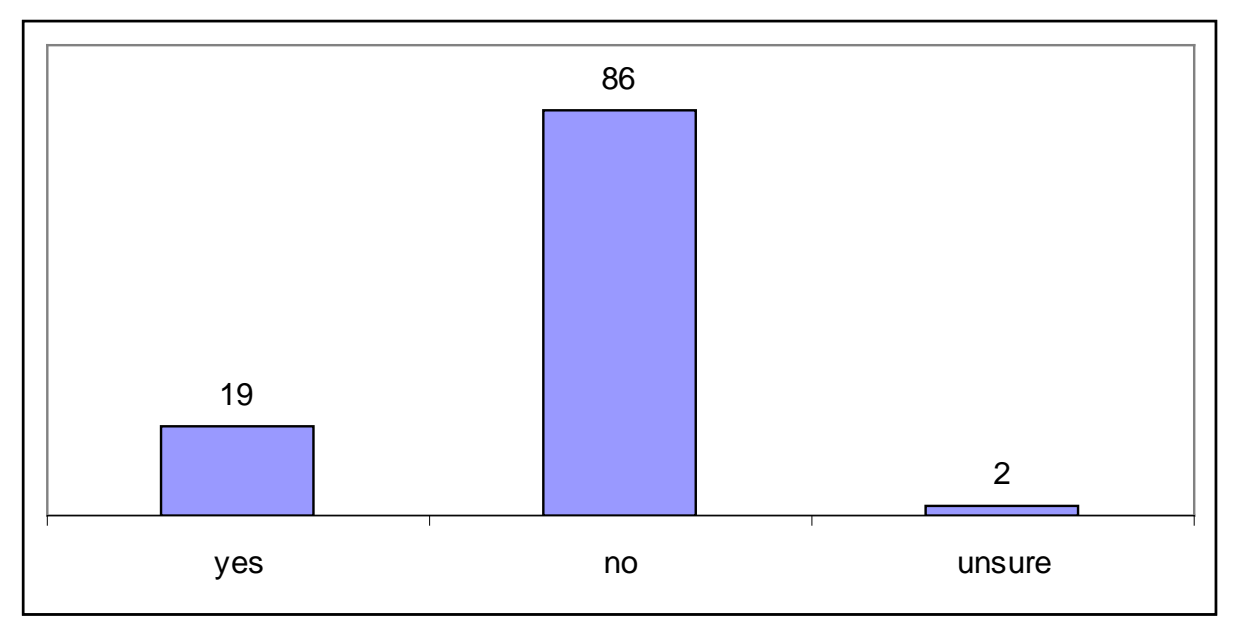

On the question of whether the public was aware of the distinction between the police authority and the police service, the overwhelming view was that 86 out of 107 responses indicated that the distinction was known.

Figure.15 Do national policing plans contradict local priorities? 


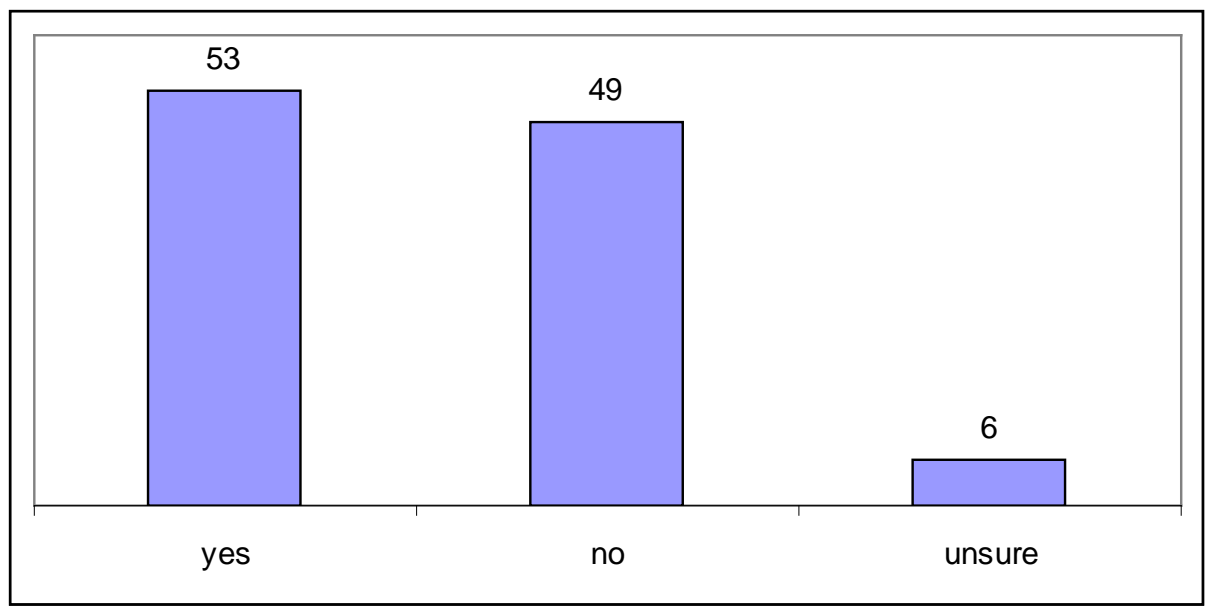

On the question of whether national policing plans were at odds with local priorities, 53 members believed that the plans did impact negatively or contradict local priorities versus 49 who did not (Fig.15). One police authority member explained that in the larger city areas there was no conflict between local and national plans because local plans were heavily dictated by the national agenda - which in itself the member argued served to demonstrate the dominance of the Home Office. The member went on to explain that in the provincial towns there was a real possibility of conflict; for example, if the national concern is with level 2 criminality (cross border issues affecting more than one basic command unit) but the local area is concerned with level 1 criminality (local crimes within a BCU). An independent member of Staffordshire Police Authority agreed that this sort of conflict did indeed occur but added that there was some inevitability to this, as some issues such as terrorism must be a national priority even though at times its implementation could conflict with local concerns.

Another interviewee from the Metropolitan Police Authority argued that the potential for conflict depended on the personality of the chief constable/commissioner and explained that chiefs of police were at times arrogant and this would have a significant affect on priorities. In another interview a member explained that he knew of one police authority where the members could not visit the police without the chief constable being informed first and agreeing to the visit. What Reiner (1991) found, however, was that most chief constables made efforts to develop good working relationships with their police authorities in order to ensure that policing policy was largely in tune with local needs.

Finally, given the complex and sometimes onerous duties placed on police authority members, the level and quality of training they receive should be mentioned. Whilst 96 
members had received regular training and 13 did not, 38 members thought that the training they had received was insufficient for the tasks they were expected to undertake: four members were unsure of its usefulness, whilst 25 respondents thought the training was sufficient. Only 29 reported that the training had been good.

\section{Conclusion}

This research has found that where there is a high level of expectation and acceptance of the need for consultation and communication; a significant number of police authority members believe that the police authority is not doing enough to represent local people. Furthermore, a significant number of police authority members questioned their own usefulness and what it was that they and the police authority were doing as far as representation was concerned.

Police authorities need to overhaul their consultative arrangements. Elliott and Nicholls (1996) found that police authorities tended to rely heavily on traditional police community style meetings but by 2003 Dalgleish et al (2003) found that police authorities had begun to reassess their methods of consultation. Raine et al, (2006) explained that good accountability depended on good communication processes and they cited that neighbourhood policing was an exciting development which if adequately resourced could deliver much in terms of public reassurance. In 2005, the Association of Police Authorities (APA) established twelve 'Accountability Pilots' led by police authorities and found that Bedfordshire, Merseyside, North Wales, Suffolk and Thames Valley each offered valuable opportunities for participation and learning by police authority members. The APA concluded that attendance at Neighbourhood Action Groups which had been established across Thames Valley, the Neighbourhood Panels in Ipswich and Suffolk and the various PCCG/CPCG and Police and Community Together (PACT) meetings would enable police authority members to hear at first hand how neighbourhood policing was working. The key priority as identified by the APA was to give opportunity for dialogue and exchange. It is clear from this research that failure to provide these opportunities will see police authorities become increasingly irrelevant to people’s everyday experience of policing.

One of the challenges for police authorities is to ensure that they are not seen as the mouth piece of the police service simply justifying and informing the community of what the police are doing (Day \& Klein, 1987; Marshall, 1978; Reiner, 2000). The other challenge for police 
authorities is that local people do not know - in sufficient number - that police authorities exist and therefore do not see themselves as having the opportunity to influence local policing through the police authority. This problem is further augmented by the fact that police authority members see the police authority as having minimal power.

Participation through consultation is therefore only meaningful if people's views can be seen to make a difference and to influence the development of policy. The litmus test of inclusion is therefore not only evidenced through participation, but in order to be viable, it must do more than simply getting people to talk, 'people must decide and do things' (McHugh \& Parvin, 2005: 22). In addition to a rigorous process, what is needed is a sense and expectation that change may ensue from one’s participation (Hoban, 2004; Parekh, 2002; Coleman, 2005).

The importance of police authority members establishing and developing local links and having local knowledge and contact is crucial if police authorities are to build trust. The Audit Commission (2003a) concluded that the notion of trust was based primarily on relationships, familiarity and experience and that people trusted individuals far more than organisations. The findings from this research conclude that police authorities need to do more to communicate what they are doing in terms of their governance and the arrangements for local policing. Secondly, the public needs to demand more from their police authority members - who are in fact their ambassadors. If police authorities continue to be ambivalent on the question of whether or not they are doing enough to represent local interests it is difficult to see how police authorities will ever be truly effective or trusted.

This research has uncovered that police authority members charged with this important responsibility have a low level of trust in their own abilities and the rigour with which they are representing the interests of the wider community. Police authorities can only be effective if members are confident in their own abilities, if they know what it is that they are doing, if they know what it is that they are supposed to do, if they have the confidence and sufficient tools to bring the chief constable/commisioner to account and if they know what questions to ask. A Grade 5 civil servant interviewee argued that far too many police authorities and in particular police authority clerks tended to be fearful of their chief constables/commissioners and they showed an alarming level of deference to them. The civil servant went on to explain that where challenges did take place they occurred within very narrow and 'almost' agreed 
boundaries which could lead one to conclude that policing by consent was by prior arrangement between the police authority and the commissionser and not by the public. On the issue of knowing which questions to ask, according to Day \& Klein (1987), police authority members lacked sufficient knowledge and understanding resulting in them being unable to ask the right questions. This situation is made worse because members are unaware of their legal powers, which invariably renders them less able to exert real influencel. However, this research has shown that a full understanding of the legal parameters of their powers may in fact have very little direct impact on the ability of the police authority to bring the police to account. What many police authority members have argued is that what is needed is an inquisitive mind and the ability to investigate. At its optimum, the police authority is a proactive, innovative and dynamic institution, supported by knowledgeable members who in turn are supported by a robust secretariat. At its minimum police authorities can be seen as functionally procedural institutions in so far as they work within the strictures which the other two members of the tripartite system permit them to work within. It is still unclear where police authority members see police authorities on the scale ranging from dynamism to functionally procedural.

The perceptible shift of power away from police authorities in favour of the Home Office and chief constables does not automatically mean that police authorities are unable to discharge their responsibilities. What it does mean however is that police authorities are somewhat restricted and constrained due to uncertainty about their remit and their position in the tripartite system. As previously discussed, chief constables can appeal directly to the home secretary and refuse to amend or to elaborate on a report that they present to their police authority. This leverage can directly undermine and inhibit the scrutiny function of the police authority. The possibility of chief constables to circumvent their police authorities in this way should be limited because the chief constable should be responsive to the wishes of his employer - the police authority.

The former Conservative Party leader Rt Hon Michael Howard MP in his speech 'Respect for Others' in Manchester (2005) suggested that increased accountability could be achieved by scrapping remote and unaccountable police authorities and replacing them with directly elected local police commissioners. Mr Howard insisted that elected commissioners would improve accountability and give the public a more direct say in the running of their local police forces and increase the citizen's influence over the type of policing and police priorities in their local areas. During an interview with the then Shadow Home Secretary - 
Chris Grayling MP - he explained that the Conservative Party's position was now more in favour of directly elected chairs of police authorities rather than elected police commissioners.

Given the inability of police authorities to influence, adequately represent the citizen, or to challenge the police, it would be easy to conclude that police authorities should be dissolved or like Rt Hon Michael Howard MP that they should have all their powers transferred to an elected mayor. Neither of these options is desirable because, transferring police authority powers to a mayor - as opposed to a Mayor chairing a police authority - would see power concentrated in too few hands and the legitimacy of a single official deciding and implementing policing policy would be questionable. There is also the other issue which is that policy would then become even more politically partisan as seen when the Mayor of London, Boris Johnson withdrew his support for the Commissioner of the Metropolitan Police Service resulting in the Commissioner - Sir Ian Blair tendering his resignation.

Whilst police authorities have a statutory responsibility to consult with the public in order to determine annual local policing priorities, there is no similar responsibility placed on the police service to consult with police authorities. A statutory responsibility should be placed on the police service that it must consult with its police authority. Bob Jones (Chair of the APA) explained that police authorities have a statutory right to ask the chief constable to report on any issue, however, the onus was on police authorities to ask questions rather than the police service to tell; a statutory responsibility reversing this and placing the onus on the police service would begin to address this imbalance.

Police authorities can also influence the national policy agenda through their representative body the, Association of Police Authorities (APA). In 2006 the APA's joint report with ACPO on the Comprehensive Spending Review (CSR) provided a positive picture of the APA and ACPO working together and calling on the government to acknowledge and address the funding gap which arose as a result of the Comprehensive Spending Review (APA, 2006). The APA has had other notable successes, for example, its response to the Home Affairs Committee inquiry into police reform and the subsequent Police Reform Act 2002 and the visible role played by the Chairman of the APA (Bob Jones) in resisting the proposed police mergers. However according to a number of interviewees the secretariat of the APA needs to be more robust, dynamic and confident in leading the policy debate on policing and in influencing the direction of travel of policy now and into the future. One area 
that the Association of Police Authorities could begin looking at is staffing. For police authorities to efficiently discharge their responsibilities there needs to be guidance and an acceptance - which is supported by funding - that a minimum level of secretariat support is required for all police authorities. The onus is therefore on the APA to argue this case on behalf of police authorities.

Responses to questions and other comments from my in-depth interviews have clearly shown that police authority members recognise gaps in their training. It therefore appears to be a sensible course of action for the APA to lobby for increased funds to support more training. I would also suggest that members of the tripartite system ought to revisit the time commitment required from members and the remuneration paid. The increasing demand on the time of police authority members makes it extremely difficult for members to serve the authority whilst undertaking other work. This can also serve as a disincentive to those who are able to offer much needed expertise on police authorities.

What is clear is that police authority members are pragmatic and they are aware that their scope of effectively holding the police to account is potentially restricted by the resource and time implications that go along with the terms of their appointment. Police authorities need to increase their effectiveness by attracting people with a wider pool of knowledge. In particular there is a deficit of members with professional business and financial expertise to augment and broaden the knowledge base of the police authority. The relationship between the police service and police authority is in some respects a relation between collaborators rather than one between a service provider and a regulator. The evidence from interviews, questionnaires and desktop research shows that whilst the functions and the responsibilities of police authorities are important, the current structure and arrangement has resulted in police authorities being seen as not fit for purpose. Any proposed changes must ensure that even if they do not directly increase democracy, they increase accountability by reconnecting the citizen with policing. 


\section{Bibliography}

Association of Police Authorities (APA). (2005). Press Release 22/12/2000, APA Website.

Association of Police Authorities (APA). (2006). [Internet], $<$ [http://www.apa.police.uk/apa] $>$, Accessed 20 $0^{\text {th }}$ August, 2006.

Audit Commission. (2003a). Trust in the Public Sector, Audit Commission Public Sector Briefing, London.

Audit Commission. (2003b). Trust in Public Institutions, Audit Commission/MORI, London.

Baldwin, R. \& Kinsey, R. (1982). Police Powers and Politics, Quartet Books, London.

Boateng, P. (1985) in Baldwin, R \& Kinsey, R (eds) (1982) Police Powers and Politics, Quartet Books, London: p.238.

Brogden, M. (1977) 'A Police Authority - A Denial of Conflict', Sociological Review, 25(2), pp.325-349.

Coleman, S. (2005). Direct Representation: Towards a Conversational Democracy, IPPR, London.

Critchley, T.A. (1978). A History of Police in England and Wales 900-1966 ( $2^{\text {nd }}$ ed), Constable, London.

Dalgleish, D., Docking, M., Myhill, A., Sindall, O., \& Yarrow, S. (2003). Involving the Public: The Role of Police Authorities: Home Office Research, Development and Statistics Directorate, London.

Dalgleish, D., Docking, M., Myhill, A. \& Yarrow, S. (2003). The Role of Police Authorities in Public Engagement: Home Office Report Online 37/03, Home Office Research, Development and Statistics Directorate, London.

Day, P. \& Klein, R. (1987). Accountabilities: Five Public Services, Tavistock Publications Ltd, London.

Docking, M. (2003). in Public Perceptions of Police Accountability and Decision Making: Home Office Online Report 38/03, Home Office Research, Development and Statistics Directorate, London.

Elliott, R. \& Nicholls, J. (1996). It's Good to Talk: Lessons in Public Consultation and Feedback, Home Office Police Research Series Paper 22: London.

Hoban, M. (2004). Let's Trust the People: Exploring a New Approach to the "Regeneration and Development" of Poor Areas, unpublished PhD thesis, Brunel University, London.

Howard, M. (2005) Leader of the Conservative Party in a Speech in Manchester, Conservative Party, [Internet], $<$ [http://www.manchesterconservatives.com]

Jones, T. \& Newburn, T. (1997). Policing After the Act: Police Governance After the Police and Magistrates' Courts Act 1994, Policy Studies Institute, London. 
Jones, T., Newburn, T. \& Smith, D. J. (1994). Democracy and Policing, Policy Studies Institute, London.

Keohane, R. O. (2002). 'Commentary on the Democratic Accountability of Non-

Governmental Organizations’, Chicago Journal of International Law, 3(2), pp.477-479.

Leicestershire Police Authority (LPA). (2007). [Internet], < [http://www.leics-

pa.police.uk/about/job-profiles/] $>$, Accessed on $1^{\text {st }}$ November, 2007.

Loveday, B. \& Reid, A. (2003). Going Local. Who Should Run Britain's Police, Policy Exchange, London.

Lustgarten, L. (1986). The Governance of Police, Sweet and Maxwell, London

Marshall, G. (1978). Police Accountability Revisited, In Butler, D. Attitudes to Crime and Criminal Justice: Findings from the 1998 British Crime Survey, Home Office Research Study 200, London

Mulgan, R. (2003). Holding Power to Account: Accountability in Modern Democracies, Palgrave MacMillan, New York.

Oliver, I. (1987). Police, Government and Accountability, Macmillan Press, London.

Parekh Report. (2002). The Future of Multi-Ethnic Britain, Runnymede Trust, London.

Policy Studies Institute (PSI). (1997). Independent Committee of Inquiry Into the Role and Responsibility of the Police, PSI, London.

Pyper, R. (ed.). (1996). Aspects of Accountability in the British System of Government. Tudor Business Publishing, Merseyside.

Raine, J., Dunstan, E. \& Patrick, R. (2006). Enhancing Accountability in Local Policing: Lessons from Twelve Police Authority Projects, Association of Police Authorities (APA), London

Reiner, R. (1991). Chief Constables: Bobbies, Bosses or Bureaucrats?, Clarendon Press, Wutton-under-Edge.

Reiner, R. (1992) The Politics of the Police, Harvester Wheatsheaf. Hemel Hempstead Reiner, R (2000) The Politics of the Police, $3^{\text {rd }}$ edition, Oxford University Press, New York Scarman Report. (1986). The Brixton Disorders: 10-12 April, 1981, Pelican Books, Harmondsworth. 